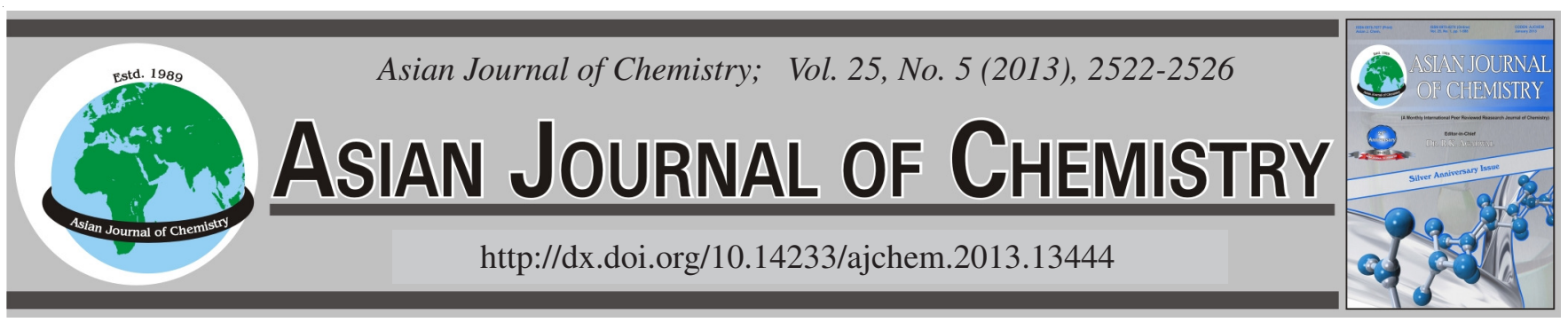

\title{
Spectrophotometric Determination of Isoniazid from Pharmaceutical Preparations Using Natural Aldehyde
}

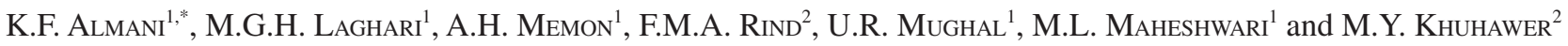

${ }^{1}$ Department of Pharmaceutics, Faculty of Pharmacy, University of Sindh, Jamshoro, Pakistan

${ }^{2}$ Dr. M.A. Kazi Institute of Chemistry, University of Sindh, Jamshoro, Pakistan

*Corresponding author: Tel: +92 33 32633835; E-mail: falmani@ hotmail.com

(Received: 14 January 2012;

Accepted: 12 November 2012)

AJC-12393

\begin{abstract}
A spectrophotometric method has been developed for the micro determination of isoniazid from various pharmaceutical dosage forms. Method is based on a condensation reaction between isoniazid and ethanolic solution of cis-cinnamaldehyde to generate an instant yellow coloured schiff's base derivative of isoniazid. The coloured product formed absorbed in visible region and optimal detector response was obtained at a wavelength of $364 \mathrm{~nm}$ with a molar absorptivity of $3.1 \times 10^{4} \mathrm{~L} / \mathrm{mol} / \mathrm{cm}$. The analytical parameters and their effects on the reported systems are investigated. A linear relationship was obtained between the absorbance and the concentration of the derivative which obeyed the Beer's law within $0.5-2.5 \mu \mathrm{g} / \mathrm{mL}$. The low \% relative standard deviation $(0.2-1.5)$ values indicate good precision, high recovery values and accuracy of proposed method.
\end{abstract}

Key Words: Isoniazid, cis-Cinnamaldehyde, Spectrophotometry.

\section{INTRODUCTION}

Isoniazid known as isoncotinyl hydrazide (INH), is first line antitubercular agent widely used together with rifampicin and streptomycin ${ }^{1,2}$. Different analytical methods have been reported for the analysis of isoniazid, based on spectrophotometric $^{3-8}$, voltametric $^{9,10}$, mass spectrometric ${ }^{11-14}$, flourimetric $^{15}$, capillary electrophoretic ${ }^{16-20}$, infra-red spectrophotometric ${ }^{21}$, thin layer chromatographic ${ }^{22}$ and high performance liquid chromatographic $\mathrm{c}^{23-25}$ techniques. For spectrophotometric analysis, the determination is carried out using either the natural absorbance of isoniazid at $262 \mathrm{~nm}$ or it is derivatized with suitable reagents such as vanillin 1 , copper(II $)^{4}$, ethyl 8quinolinoxy acetate $^{5}, 6,7$-dichloroquinoline-5,8-dione ${ }^{6}, 2,3$ dichloro-1,4-naphthoquinone ${ }^{7}$, trans-cinnamaldehyde ${ }^{8}$, cerium (IV) ${ }^{15}$ and 5-methylfuran-2-carboxaldehyde ${ }^{24}$. The derivatization increases the molar absorptivity of the drug with bathochromic shift.

Eidus and Harnanansingh ${ }^{8}$ used trans-cinnamaldehyde as derivatizing reagent and measured maximum absorbance at $340 \mathrm{~nm}$ but in present method cis-cinnamaldehyde is used as a reagent with measurement of absorbance at $364 \mathrm{~nm}$ at $\mathrm{pH}$ 9.5. The developed method is applied for the determination of isoniazid from pharmaceutical preparations. The method does not require solvent extraction.
Proposed method is based on the condensation reaction between isoniazid and ethanolic solution of cis-cinnamaldehyde in boric acid medium $\mathrm{pH} 9.5$ to form a yellow coloured Schiff's base having absorption maximum at $364 \mathrm{~nm}$. The proposed method is free from the interference of the excipients normally found along with isoniazid in various pharmaceutical dosage forms and excess of derivatizing reagent. Further, the method is found to possess adequate accuracy and precision.

\section{EXPERIMENTAL}

All the reagents and chemicals of analytical or pharmaceutical grades were used. The double distilled water used throughout the study was obtained from distillation plant all made of glass. Pure isoniazid, cis-cinnamaldehyde, (CIN) and acetic acid from E. Merck, (Germany), sodium acetate and ethanol from Fluka, (Switzerland) were used. Buffer solutions between $\mathrm{pH} 1-10$ at unit interval were prepared from $0.1 \mathrm{M}$ of hydrochloric acid, potassium chloride, acetic acid, sodium acetate, sodium bicarbonate, sodium carbonate, boric acid, sodium hydroxide, ammonium chloride and ammonia solution. The solution of cis-cinnamaldehyde ( $2 \% \mathrm{v} / \mathrm{v})$ was prepared in ethanol. The spectrophotometric studies were carried out with a double beam spectrophotometer (UV/visible spectrometer Lambda 25, Perkin-Elmer, USA) with dual silica $1 \mathrm{~cm}$ cuvettes. The spectrophotometer was controlled by the 
computer with UV WinLab Lambda 25 software. $\mathrm{pH}$ meter (Schot Instrument Lab 850, Germany) with glass electrode and internal reference was used.

Analytical procedure with derivatization: The aqueous solution (0.5-2.5 mL) containing isoniazid (2.5-12.5 $\mu \mathrm{g})$ was transferred to a series of $5 \mathrm{~mL}$ calibrated well stoppered volumetric flasks and were added $0.6 \mathrm{~mL}$ cis-cinnamaldehyde (ethanolic $2 \%$ ), followed by borate-sodium hydroxide buffer $\mathrm{pH}$ $9.5(0.5 \mathrm{~mL})$. The contents were heated on water bath at $95 \pm 5^{\circ} \mathrm{C}$ for $10 \mathrm{~min}$. The solutions were cooled at room temperature and the volumes were adjusted to mark with ethanol. The absorbance was measured at $364 \mathrm{~nm}$ against reagent blank which was prepared in a similar way only omitting the addition of isoniazid.

Procedure without derivatization: The aqueous isoniazid solution $(0.2-1.0 \mathrm{~mL})$ containing isoniazid $(20-100 \mu \mathrm{g})$ was transferred to $5 \mathrm{~mL}$ calibrated well stoppered volumetric flasks and the volumes were adjusted to mark with water. The absorbance was measured at $262 \mathrm{~nm}$ against water and the molar absorptivity was calculated $3.9 \times 10^{3} \mathrm{~L} / \mathrm{mol} / \mathrm{cm}$.

Analysis of isoniazid from pharmaceutical preparations: Twenty samples of different pharmaceutical companies were collected and were subjected for the analysis of isoniazid. The powdered sample $(0.1 \mathrm{~g})$ from each of the following preparation Rifazol Junior, Rifa-4 (Schazoo Zaka Lahore, Pakistan), Isozide (Nabiqasim Industries (Pvt.) Ltd., Karachi, Pakistan), Polyzide (Polyfine Chem Pharma, (Pvt.) Ltd, Peshawar, Pakistan), Isoniazid, Rifa-plus (Unexo Labs (Pvt.) Ltd., Lahore, Pakistan), Isoniazide (Jawa Pharmaceuticals (PVT) Ltd. Lahore, Pakistan), Rifinah (Pacific Pharmaceuticals Ltd. Lahore, Pakistan), Myrin-P, Myambutol (Wyeth Pakistan Ltd., Karachi.), Rimatol (Dosaco Laboratories Lahore, Pakistan), Acoret (Efroze Chemical Industries (Pvt.) Ltd. Karachi, Pakistan), Afrazid (Consolidated Chemical Laboratories (Pvt) Ltd. Lahore, Pakistan), Cyrex (Rex Pharmaceuticals Pakistan), Fairzide (Ferro Pharmaceutical Laboratories, Pakistan), isoniazid, Rifazid Forte (Geofman Pharmaceuticals, Karachi, Pakistan), I.N.H. (P.D.H. Pharmaceuticals (Pvt) Ltd. Lahore, Pakistan), Isoniazid (Lahore Chemical \& Pharmaceutical Works (Pvt.) Ltd., Lahore, Pakistan), Isoniazid (Genera Pharmaceuticals, Islamabad, Pakistan), Rifampicin (Zafa Pharmaceutical Laboratories (Pvt.) Ltd. Karachi, Pakistan) preparation was dissolved/diluted separately in distilled water and filtered through Whatman No. 1 filter paper, volumes were adjusted to $100 \mathrm{~mL}$ with water. The solution $(0.5 \mathrm{~mL})$ from each of the $100 \mathrm{~mL}$ solutions of all brands was further transferred to separate $100 \mathrm{~mL}$ calibrated well stoppered flasks and the volumes were made up to the mark with distilled water $(0.0005 \%)$. Finally $02 \mathrm{~mL}$ from each of the solution of each preparation was taken in separate $5 \mathrm{~mL}$ volumetric flask and the procedure was repeated as described in analytical procedure. The amount of isoniazid from each of the sample was calculated using the external calibration curve (Tables 1-4).

\begin{tabular}{cccc}
\multicolumn{4}{c}{ TABLE-1 } \\
ANALYSIS OF INH FROM SACHET \\
(AMOUNT LABELED 30 mg/SACHET)
\end{tabular}

TABLE-2

\begin{tabular}{|c|c|c|c|}
\hline \multicolumn{4}{|c|}{$\begin{array}{c}\text { TABLE-2 } \\
\text { ANALYSIS OF INH FROM SYRUPS } \\
\text { (AMOUNT LABELED } 50 \mathrm{mg} / 5 \mathrm{~mL} \text { ) }\end{array}$} \\
\hline Drug & $\begin{array}{c}\text { Amount } \\
\text { found }(\mathrm{mg} / 5 \\
\mathrm{mL})(\mathrm{RSD} \%)\end{array}$ & $\begin{array}{c} \pm \text { Relative } \\
\text { deviation }(\%) \text { from } \\
\text { labeled values }\end{array}$ & $\begin{array}{l}\text { Recovery }(\%) \text { by } \\
\text { standard addition } \\
\text { technique }\end{array}$ \\
\hline Isozide & $50.3(0.9)$ & 0.5 & 98.9 \\
\hline Polyzide & $50.0(0.4)$ & 0.0 & 99.0 \\
\hline
\end{tabular}

\begin{tabular}{lcccc}
\multicolumn{5}{c}{ TABLE-3 } \\
\multicolumn{1}{c}{ Drug } & $\begin{array}{c}\text { Labeled } \\
\text { amount } \\
\text { (mg)/tablet }\end{array}$ & $\begin{array}{c}\text { Amount } \\
\text { found } \\
(\mathrm{mg}) / \text { tablet } \\
\text { (RSD \%) }\end{array}$ & $\begin{array}{c} \pm \text { Relative } \\
\text { deviation } \\
(\%) \text { from } \\
\text { labeled } \\
\text { values }\end{array}$ & $\begin{array}{c}\text { Recovery } \\
(\%) \text { by } \\
\text { standard } \\
\text { addition } \\
\text { technique }\end{array}$ \\
\hline Isoniazid & 50 & $49.3(1.5)$ & 1.4 & 99.8 \\
Isoniazide & 50 & $49.6(1.1)$ & 0.8 & 98.3 \\
Rifinah & 50 & $48.8(1.4)$ & 2.4 & 97.9 \\
Myrin-P & 60 & $58.9(0.4)$ & 1.8 & 98.2 \\
Rifa 4 & 60 & $59.8(0.2)$ & 0.3 & 99.0 \\
Rimatol & 60 & $59.2(0.9)$ & 1.4 & 99.5 \\
Acoret & 75 & $74.0(1.0)$ & 1.3 & 100 \\
Afrazid & 75 & $74.9(0.3)$ & 0.13 & 99.7 \\
Cyrex & 75 & $75.0(0.5)$ & 00 & 98.6 \\
Fairzide & 100 & $98.9(0.6)$ & 1.8 & 97.9 \\
Isoniazid & 100 & $100(1.1)$ & 00 & 97.4 \\
INH & 100 & $99.9(0.6)$ & 0.01 & 99.0 \\
Isoniazid & 100 & $99.8(0.3)$ & 0.2 & 99.8 \\
Isoniazid & 100 & $99.1(0.7)$ & 0.4 & 95.9 \\
Myambutol & 100 & $98.0(1.6)$ & 2 & 99.8 \\
Rifa+Plus & 100 & $99.5(1.4)$ & 0.5 & 99.6 \\
\hline
\end{tabular}

\section{RESULTS AND DISCUSSION}

Isoniazid (INH) or isonicotinyl hydrazide reacts with ciscinnamaldehyde (CIN) to form an imine INH-CIN derivative (Fig. 1). The derivative absorbs at $364 \mathrm{~nm}$ maximally with bathochromic shift having molar absorptivity of $3.1 \times 10^{4}$ $\mathrm{L} / \mathrm{mol} / \mathrm{cm}$. The free CIN was then examined as a derivatizing reagent for the spectrophotometric determination of isoniazid. The amount of CIN added, effects of $\mathrm{pH}$, heating time and temperature and the stability of the (INH-CIN) derivative were studied carefully.

\section{Optimization of parameters}

Analytical wavelength: For the quantitative analysis, the wavelength of maximum absorbance plays an important role. It is compulsory to ensure that pure analyte and derivatizing

TABLE-4

ANALYSIS OF INH FROM CAPSULES

\begin{tabular}{lcccc}
\hline \multicolumn{1}{c}{ Drug } & $\begin{array}{c}\text { Labeled amount } \\
(\mathrm{mg}) / \text { capsule }\end{array}$ & $\begin{array}{c}\text { Amount found } \\
(\mathrm{mg}) / \text { capsule (RSD \%) }\end{array}$ & $\begin{array}{c}\text { 住elative deviation }(\%) \\
\text { from labeled values }\end{array}$ & $\begin{array}{c}\text { Recovery (\%) by standard } \\
\text { addition technique }\end{array}$ \\
\hline Rifampicin + INH & 150 & $149(1.0)$ & 0.6 & 99.7 \\
Rifazid forte & 150 & $149.8(0.2)$ & 0.13 & 98.6 \\
\hline
\end{tabular}




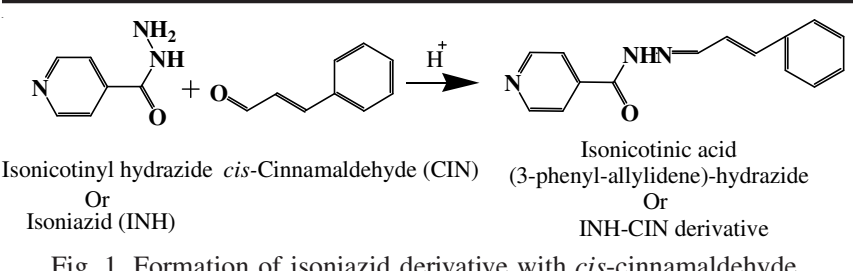

Fig. 1. Formation of isoniazid derivative with cis-cinnamaldehyde

reagent should not absorb near to the region where the analyte derivative absorbs. This may cause inaccuracy in absorption of the drug because of the derivatization. The excess volume of derivatizing reagent is added to complete the reaction quantitatively. To stay away from this hinder, it is compulsory to select the wavelength where the analyte derivative shows maximum absorbance and the derivatizing reagent indicates minimum absorbance. The maximum absorbance value of $20-100 \mu \mathrm{g} / \mathrm{mL}$ of pure isoniazid without derivatization and $0.5-2.5 \mu \mathrm{g} / \mathrm{mL}$ of INH-CIN derivative was recorded at different wavelengths between 550-200 $\mathrm{nm}$ after heating for $10 \mathrm{~min}$ at $95{ }^{\circ} \mathrm{C}$ using borate-sodium hydroxide buffer $\mathrm{pH}$ 9.5. It was noted that the maximum absorbance occurs at $364 \mathrm{~nm}$ against reagent blank. Therefore, the wavelength of $364 \mathrm{~nm}$ was selected as optimum wavelength $\left(\lambda_{\max }\right)$ for INH-CIN derivative while $262 \mathrm{~nm}$ was observed for pure isoniazid (Fig. 2).

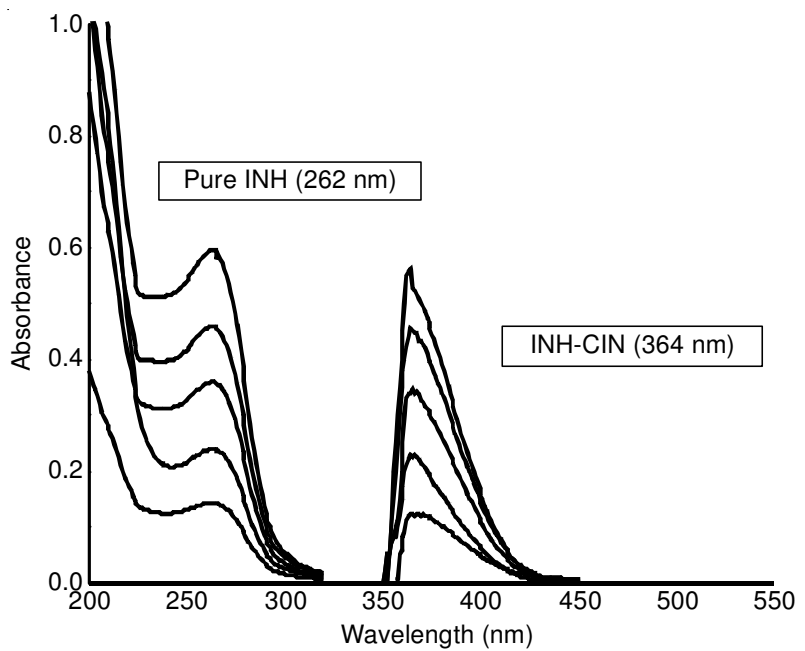

Fig. 2. Optimization of analytical wavelength

Effect of reagent concentration: The effects of adding various amounts of CIN solution on absorbance of $02 \mu \mathrm{g} / \mathrm{mL}$ INH-CIN derivative is given in Fig. 3. The volume of $2 \%$ ethanolic CIN was varied between $0.2-1.2 \mathrm{~mL}$ with an interval of $0.2 \mathrm{~mL}$ and the absorbance was measured at $\lambda_{\max } 364 \mathrm{~nm}$. Primarily the absorbance was improved slowly and then the similar absorbance was observed with addition of $0.6 \mathrm{~mL}$ and above, it was therefore the addition of $0.6 \mathrm{~mL}(2 \% \mathrm{v} / \mathrm{v}$ in ethanol) CIN solution was selected.

Effect of order of mixing the reagents: The order of adding the reagent during derivatization process has important part in precision of results and enhancement of absorbance. In this study, it was observed that the addition of $2.5 \mathrm{~mL}$ isoniazid solution to buffer $\mathrm{pH} 9.5(0.5 \mathrm{~mL})$ followed by 0.6 $\mathrm{mL}$ reagent (CIN) resulted in a decrease in absorbance value. Taking the buffer $\mathrm{pH} 9.5$ first and then adding the reagent $\mathrm{CIN}$, followed by isoniazid solution also gave lower absorbance

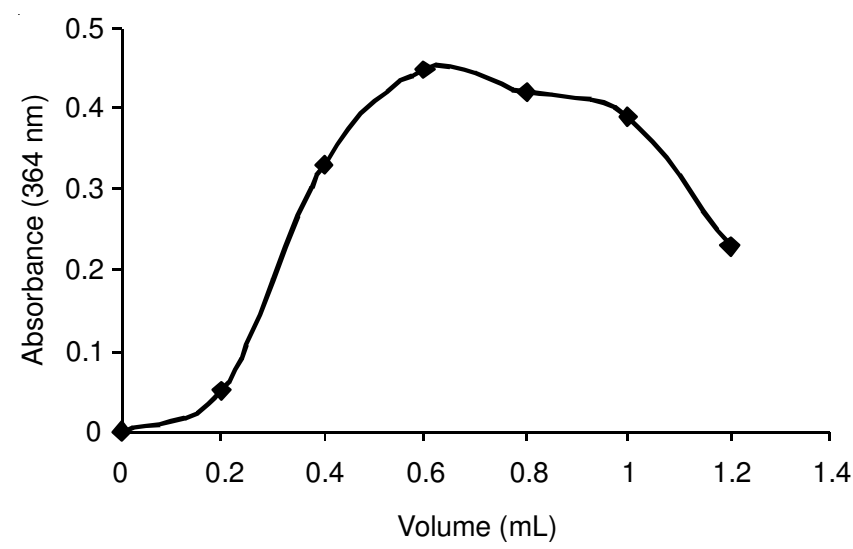

Fig. 3. Effect of volume of reagent CIN $2 \%$ ethanolic on absorbance of isoniazid derivative

value. It was observed that the maximum absorbance value accomplished when $0.6 \mathrm{~mL}$ of reagent CIN was added to the standard solution of isoniazid followed by buffer $(0.5 \mathrm{~mL}) \mathrm{pH}$ 9.5. The contents were then heated on water bath and the volume was adjusted to the mark with ethanol.

Optimization of heating time and temperature for the formation of derivative: To obtain the maximum absorbance value for derivative, the selection of optimum time and temperature for the formation of unwavering derivative are essential factors. The effect of time and temperature on absorbance of $02 \mu \mathrm{g} / \mathrm{mL}$ isoniazid solution in the presence of $2 \%$ CIN solution was checked at $364 \mathrm{~nm}$ from 0-30 min with an interval of $5 \mathrm{~min}$ at $95 \pm 5^{\circ} \mathrm{C}$. A similar absorbance was observed after heating for $10 \mathrm{~min}$, so, heating for $10 \mathrm{~min}$ at 95 $\pm 5^{\circ} \mathrm{C}$ was considered as optimal heating time and temperature for derivatization.

Effect of solvents: The effect of various solvents such as methanol, 1-propanol, 1-butanol, 2-propanol, amyl alcohol, isoamyl alcohol, acetonitrile and ethyl acetate on the absorbance of $02 \mu \mathrm{g} / \mathrm{mL}$ INH-CIN derivative was examined. Each of the solvent 0.5 and $01 \mathrm{~mL}$ was added after the addition of $2 \%$ ethanolic solution of $\mathrm{CIN}$ and $0.5 \mathrm{~mL}$ borate buffer $\mathrm{pH}$ 9.5 followed by heating for $10 \mathrm{~min}$. The ethanol proved to be the best choice in solvents.

Effect of $\mathbf{p H}$ : The effect of adding $0.5 \mathrm{~mL}$ of $0.1 \mathrm{M}$ buffers of $\mathrm{pH}$ range $1-10$ on the absorbance of $2.5 \mu \mathrm{g} / \mathrm{mL}$ INH-CIN derivative solution at already maximized conditions was studied. It was observed that, with; buffer $\mathrm{HCl}-\mathrm{KCl} \mathrm{pH} \mathrm{1-3}$ the absorbance was poor, acetate buffer $\mathrm{pH}$ 4-7 has very low absorbance, $\mathrm{NaOH}-\mathrm{NaCl}$ buffer $\mathrm{pH}$ 8-10 decreased absorbance and $\mathrm{NaCO}_{3}-\mathrm{NaHCO}_{3} \mathrm{pH}$ 8-10 shown low absorbance and $\mathrm{pH}$ 11 produced turbidity. The absorbance increased gradually with borate buffer $\mathrm{pH} 7$ and it was maximum at $\mathrm{pH} 9.5$ (Fig. 4). Addition of buffer above $\mathrm{pH} 9.5$ decreased absorbance. Therefore, the borate buffer of $\mathrm{pH} 9.5$ was selected as optimal.

Interference study: The effect of possible presence of water soluble associated materials such as acacia, ethambutol, fructose, glucose, galactose, mannitol, lactose, pyrizinamide, rifampicin, sorbitol, sucrose, starch, sodium chloride and talc was investigated at double and 10 times the concentration of isoniazid and it was observed that none of these substances interfered by showing any change in absorbance more than \pm $2 \%$ (Table-5). 


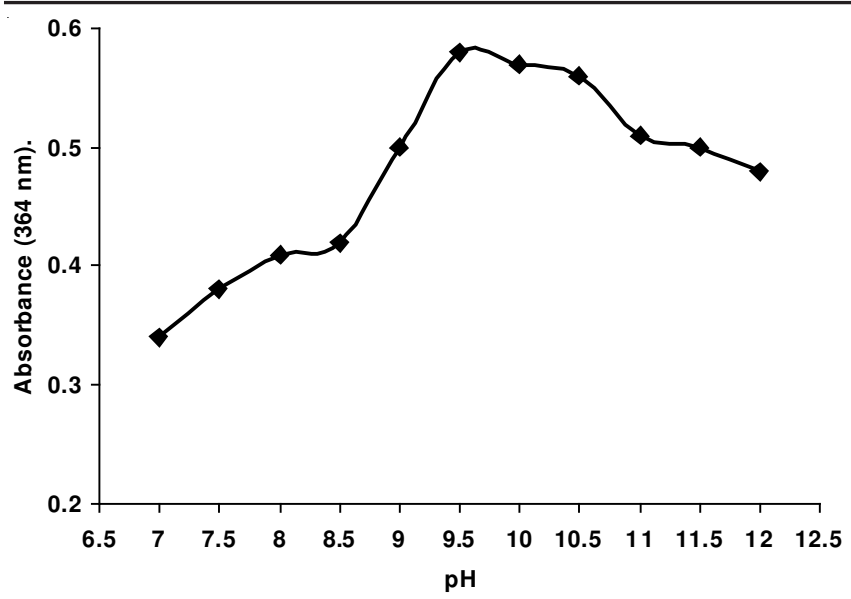

Fig. 4. Effect of $\mathrm{pH}$ on derivatization of isoniazid

\begin{tabular}{lccc}
\multicolumn{4}{c}{ TABLE-5 } \\
\multicolumn{4}{c}{ EFFECT OF DIFFERENT POSSIBLE EXCIPIENTS ON THE } \\
ABSORBANCE OF 02 $\mu \mathrm{g} / \mathrm{mL}$ INH-CIN DERIVATIVE \\
\hline $\begin{array}{l}\text { Excipient added } \\
(25 \mu \mathrm{g} / \mathrm{mL})\end{array}$ & $\begin{array}{c}\text { Absorbance } \\
\text { at }(460 \mathrm{~nm})\end{array}$ & $\begin{array}{c}\text { Relative } \\
\text { error }(\%)\end{array}$ & $\begin{array}{c}\text { Recovery of drug } \\
(\%) \pm \text { RSD } \%(\mathrm{n}=3)\end{array}$ \\
\hline- & 0.451 & - & - \\
Acacia & 0.441 & -2.2 & $98.9 \pm 0.27$ \\
Ethambutol & 0.451 & 00 & $99.9 \pm 0.34$ \\
Fructose & 0.449 & -4.4 & $99.3 \pm 0.32$ \\
Glucose & 0.440 & -2.4 & $98.3 \pm 0.22$ \\
Galactose & 0.448 & -0.6 & $99.0 \pm 0.35$ \\
Mannitol & 0.441 & -2.2 & $99.4 \pm 0.28$ \\
Lactose & 0.450 & -0.2 & $99.7 \pm 0.35$ \\
Pyrizinamide & 0.451 & 00 & $100.2 \pm 0.30$ \\
Rifampicin & 0.451 & 00 & $100.4 \pm 0.25$ \\
Sorbitol & 0.450 & -0.20 & $99.6 \pm 0.34$ \\
Sucrose & 0.447 & -0.88 & $99.3 \pm 0.28$ \\
Starch & 0.452 & 0.22 & $99.5 \pm 0.35$ \\
Sodium chloride & 0.456 & 1.10 & $99.6 \pm 0.30$ \\
Talc & 0.443 & -1.70 & $99.7 \pm 0.35$ \\
\hline
\end{tabular}

Calibration plot: The effect of variation in the concentration of isoniazid on its absorbance as derivative INH-CIN was studied. A linear calibration curve was obtained which obeyed the Beer's law within the concentration range 0.5-2.5 $\mu \mathrm{g} / \mathrm{mL}$ of isoniazid with coefficient of determination $\mathrm{r}^{2} 0.9992$ (Fig. 5).

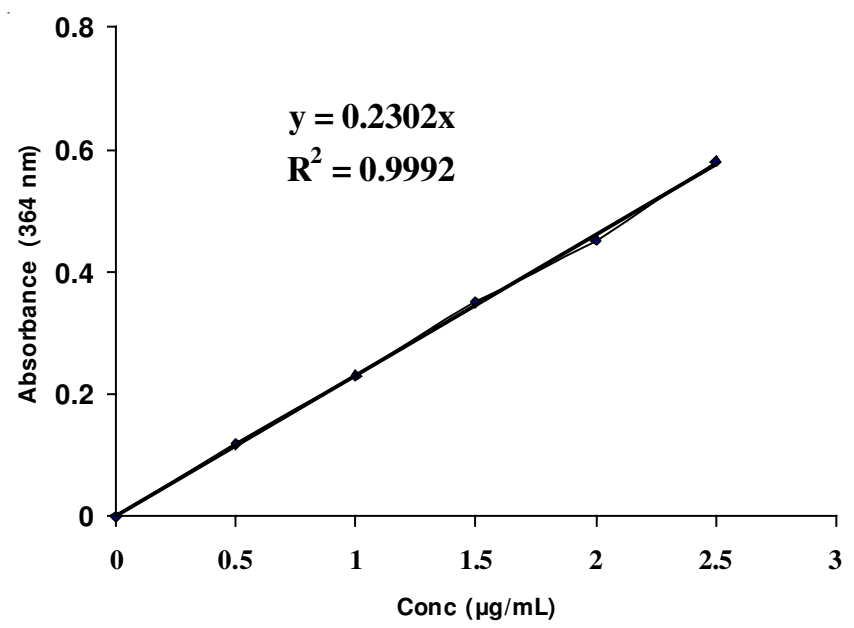

Fig. 5. Calibration curve of isoniazid using cis-cinnamaldehyde as derivatizing reagent
Analytical data: The optical characteristics such as Beer's law limits, Sandell's sensitivity, relative standard deviation, range of error at $95 \%$ confidence limit, molar absorptivity, limit of detection (LOD) and limit of quantification (LOQ) were calculated and the results are summarized in Table- 6 . LOD and LOQ were calculated by equations LOD $=\delta 3.3 / \mathrm{s}$ and LOQ $=\delta 10 / \mathrm{s}$, respectively, where $\delta$ is the standard deviation of blank and $\mathrm{s}$ is slope of calibration. Regression analysis of the Beer's law plot at their $\lambda_{\max } 364 \mathrm{~nm}$ exposed a good correlation. The mean values $\mathrm{mg} / \mathrm{sample}$ at range of error $\%$ at $90 \%$ confidence limit of $30 \mathrm{mg} / \mathrm{sachet}, 50 \mathrm{mg} / 5 \mathrm{~mL}$ syrup, 60,75 and $100 \mathrm{mg}$ tablets and $150 \mathrm{mg}$ isoniazid capsules were $29.9 \pm 0.2107,50.15 \pm 2.9,49.2 \pm 2.1,59.3 \pm 0.85,74.6 \pm$ $1.0,99.3 \pm 0.75$ and $149 \pm 2.7$, respectively.

Stability of the derivative: The stability of INH-CIN derivative was examined in terms of absorbance at the concentration of $02 \mu \mathrm{g} / \mathrm{mL}$ INH-CIN derivative, but no change in absorbance of more than $3 \%$ was observed within $48 \mathrm{~h}$.

Recovery $(\%)$ of isoniazid from samples by standard addition technique: The reliability and validity of the proposed method was evaluated by standard addition technique. Isoniazid standard $(0.0005 \mathrm{~g})$ was dissolved in $100 \mathrm{~mL}$ double distilled water. Two portions, each consisting $2 \mathrm{~mL}$ were taken in two different volumetric flasks $(5 \mathrm{~mL})$. One was added with 0.5 $\mathrm{mL}$ of sample solution containing $5 \mu \mathrm{g} / \mathrm{mL}$ of isoniazid and the derivatization procedure was repeated for both solutions as described in analytical procedure. The $\%$ recoveries were calculated using Recovery $(\%)=\left[\left(\mathrm{C}_{\mathrm{t}}-\mathrm{C}_{\mathrm{s}}\right) / \mathrm{C}_{\mathrm{a}}\right] \times 100$ from the increase in the absorbance with added standard (Tables 2-5). Here $C_{t}$ is the total drug concentration measured after standard addition; $\mathrm{C}_{\mathrm{s}}$, drug concentration in the formulation sample; $\mathrm{C}_{\mathrm{a}}$, drug concentration added to formulation.

Day to day reproducibility/repeatability: For the determination of intra and interday reproducibility of the method, aqueous standard solution $(0.5 \mathrm{~mL})$ of $5 \mu \mathrm{g} / \mathrm{mL}$ isoniazid was taken in three different calibrated volumetric flasks $(5 \mathrm{~mL})$ and the procedure was followed for each solution as described in analytical procedure. The absorbance was measured against reagent blank at $364 \mathrm{~nm}$. The above procedure was repeated for three days $(n=3)$. The mean absorbances of intraday and interday reproducibilities were observed as 0.13 and 0.12 with (RSD \%) values 0.43 and 0.21 , respectively.

Application of the proposed method: The proposed method was applied to the determination of isoniazid in commercially available single and multiple ingredient capsules, sachet, syrups and tablets. The same samples were analyzed, simultaneously by thee method without derivatization.

\section{Conclusion}

Simple, economical, selective and sensitive spectrophotometric method was developed and validated. The proposed method does not require expensive and hazardous reagents and sophisticated instruments. The statistical parameters and recovery study data indicate the reproducibility and accuracy of the method. Analysis of the pharmaceutical preparations containing isoniazid as single drug as well as multiple ingredients showed no interference from the common excipients. So, this method could be considered for the determination of isoniazid in pharmaceutical quality control laboratories. 
TABLE-6

RESULTS OF OPTIMIZATION, PRECISION AND ACCURACY

\begin{tabular}{|c|c|}
\hline Parameter (s) & Selected values \\
\hline Wave length $\lambda_{\max }$ of INH-CIN derivative & $364 \mathrm{~nm}$ \\
\hline Beer's law limits $(\mu \mathrm{g} / \mathrm{mL})$ of INH-CIN derivative & $0.5-2.5$ \\
\hline Wave length $\lambda_{\max }$ of INH & $262 \mathrm{~nm}$ \\
\hline Beer's law limits $(\mu \mathrm{g} / \mathrm{mL})$ of INH & $4-20$ \\
\hline Molar absorptivity $(\mathrm{L} / \mathrm{mol} / \mathrm{cm})$ of INH-CIN derivative & $3.1 \times 10^{4}$ \\
\hline Molar absorptivity $(\mathrm{L} / \mathrm{mol} / \mathrm{cm})$ of INH & $3.9 \times 10^{3}$ \\
\hline Sandell's sensitivity of INH-CIN (Conc. $\mu \mathrm{g} / \mathrm{mL}$ at 0.005 absorbance unit) & 0.08 \\
\hline \multicolumn{2}{|l|}{ Regression equation (y) a } \\
\hline Slope (b) & 0.2302 \\
\hline Intercept (a) & 0 \\
\hline Coefficient of determination $\left(\mathrm{r}^{2}\right)$ & 0.9992 \\
\hline Relative Standard deviation (\%) & $1.6-0.2$ \\
\hline Relative deviation $( \pm \%)$ & $2.4-0$ \\
\hline $\mathrm{LOD}(\mu \mathrm{g} / \mathrm{mL})$ & 0.1 \\
\hline $\mathrm{LOQ}(\mu \mathrm{g} / \mathrm{mL})$ & 0.4 \\
\hline $\begin{array}{l}\text { Mean value } \mathrm{mg} / 5 \mathrm{~mL} \text { of syrup } \pm \text { range of error } \% \text { at ( } 95 \% \text { confidence limit }) \text { of two syrups }(50 \mathrm{mg} / 5 \mathrm{~mL}) \text { of various } \\
\text { pharmaceutical companies }\end{array}$ & $50.15 \pm 1.1$ \\
\hline Mean value $\mathrm{mg} / \mathrm{tablet} \pm$ range of error $\%$ at ( $95 \%$ confidence limit) of three tablets ( $50 \mathrm{mg}$ ) of various pharmaceutical companies & $49.2 \pm 1.8$ \\
\hline Mean value $\mathrm{mg} / \mathrm{tablet} \pm$ range of error $\%$ at ( $95 \%$ confidence limit) of three tablets $(60 \mathrm{mg}$ ) of various pharmaceutical companies & $59.3 \pm 0.85$ \\
\hline Mean value $\mathrm{mg} / \mathrm{tablet} \pm$ range of error $\%$ at (95\% confidence limit) of three tablets $(75 \mathrm{mg}$ ) of various pharmaceutical companies & $74.6 \pm 1.0$ \\
\hline $\begin{array}{l}\text { Mean value } \mathrm{mg} / \mathrm{tablet} \pm \text { range of error } \% \text { at ( } 95 \% \text { confidence limit) of seven tablets }(100 \mathrm{mg} \text { ) of various pharmaceutical } \\
\text { companies }\end{array}$ & $99.3 \pm 0.75$ \\
\hline $\begin{array}{l}\text { Mean value } \mathrm{mg} / \mathrm{tablet} \pm \text { range of error } \% \text { at ( } 95 \% \text { confidence limit) of two capsules }(150 \mathrm{mg} \text { ) of various pharmaceutical } \\
\text { companies }\end{array}$ & $149.3 \pm 1.2$ \\
\hline
\end{tabular}

\section{REFERENCES}

1. E.F. Oga, Int. J. Pharm. Pharm. Sci., 2, 55 (2010).

2. G.K. Naidu, K. Suvardhan, K.S. Kumar, D. Rekha, B.S. Sastry and P. Chiranjeevi, J. Anal. Chem., 60, 822 (2005).

3. M.B. Devani, C.J. Shishoo, M.A. Patel and D.D. Bhalara, J. Pharm. Sci., 67, 661 (1978).

4. A. Safavi, M.A. Karimi, M.R.H. Nezhad, R. Kamali and N. Saghir, Spectrochim. Acta A, 60, 765 (2004).

5. A.H.N. Ahmed, S.M.E. Gizawy and H.I.E Subbagh, Anal. Lett., 25, 73 (1992).

6. M.E. El-Kommos and A.S. Yanni, Analyst, 113, 1091 (1988).

7. M.B. Devani, C.J. Shishoo, M.A. Patel and D.D. Bhalara, J. Pharm. Sci., 67, 661 (1978).

8. L. Eidus and A.M.T. Harnanansingh, Clin. Chem., 17, 492 (1971).

9. M.R. Majidi, A. Jouyban and K.A. Zeynali, Electroanalysis, 17, 915 (2005).

10. H.Y. Xia and X. Ya Hu, Anal. Lett., 38, 1405 (2005).

11. P.-F. Fang, H.L. Cai, H.D. Li, R.H. Zhu, Q.Y. Tan, W. Gao, P. Xu, Y.P. Liu, W.Y. Zhang, Y.C. Chen and F. Zhang, J. Chromatogr. B, 878, 2286 (2010).

12. B.H. Lauterburg, C.V. Smith and J.R. Mitchell, J. Chromatogr. B, 224, 431 (1981).

13. K. Ng, H. Zhou, Y.L. Zhang, B. Hybertson, T. Randolph and U. Christians, J. Chromatogr. B, 847, 188 (2007).
14. H. Zhou, Y. Zhang, D.L. Biggs, C.M. Manning, T.W. Randolph, U. Christians, B.M. Hybertson and K. Ng, J. Control. Rel., 107, 288 (2005).

15. R.A.S. Lapa, J.L.F.C. Lima and J.L.M. Santos, Anal. Chim. Acta, 419 , 17 (2000).

16. X. Zhang, Y. Xuan, A. Sun, Y. Lv and X. Hou, J. Luminescence, 24, 243 (2009).

17. W. Er-Kang and Z. Wei-Hong, Chin. J. Chem., 14, 131 (1999).

18. J. Liu, W. Zhou, T. You, F. Li, E. Wang and S. Dong, Anal. Chem., 68, 3350 (1996).

19. W. Jin-li, Z. Zhu-jun, W. Ke and X. Lei, Chin. J. Anal. Lab., 6 (2009).

20. P. Kowalski, J. Pharm. Biomed. Anal., 43, 222 (2007).

21. A. Borba, A. Gmez-Zavaglia and R. Fausto, J. Phys. Chem. A, 113, 9220 (2009).

22. M. Hashiguchi, K. Ohno, A. Sakuma, F. Hino,T. Tanaka, M. Ohtsuji, N. Matsumoto, K. Yanase, A. Urae, Y. Hosogai, N. Sato, A. Yazaki, K. Matsuda, K. Yamazaki and T. Rikihisa, J. Clin. Pharmacol., 42, 151 (2002).

23. A.G. Butterfield, E.G. Lovering and R.W. Sears, J. Pharm. Sci., 69, 222 (1980).

24. M.Y. Khuhawar, F.M.A. Rind and A.D. Rajper, Acta Chromatogr., 15, 269 (2005).

25. E. Sottofattori, R. Raggio and O. Bruno, J. Chem. Educ., 80, 547 (2003). 